\title{
THE GROWTH, HEALTH AND FOOD OF A SINGLE INFANT
}

\author{
BY \\ NANCY B. BRANSBY and E. R. BRANSBY
}

(RECEIVED FOR PUBLICATION MAY 31, 1952)

This note concerns the weight, growth, health and food of a girl from the ages of $9 \frac{1}{2}$ to $52 \frac{1}{2}$ weeks.

The child, the fifth of her parents, was born on December 19, 1950. The birth was normal and the birth weight was $7 \mathrm{lb}$. $3 \mathrm{oz}$. She was fully breast fed for a few days and then partly so for about eight weeks. From one week after weaning a record was kept weekly of the food she ate, except for one spell of two weeks and two spells of four weeks. The amount of food eaten was found by weighing the tins of food at the beginning and end of the week, and by taking account of any food wasted. Foods such as egg and soup were noted in spoonfuls as eaten. The child ate little bread or rusks up to the age of 1 year; there was thus no trouble about wastage of such foods. The child was content and happy during the 43 weeks of the study, except, of course, during illness. She was in fact a model baby.

\section{Results}

Amount of Foods Eaten. The amount of milk taken was fairly steady during the whole time at about $27 \mathrm{oz}$. of full cream milk powder a week. The amount of sugar too was steady at about $6 \mathrm{oz}$. a week. Cereals were first eaten at the age of 12 weeks, the amount taken reaching $10 \mathrm{oz}$. per week at 15 weeks, which then varied from week to week with an upward trend. Bone broth was given at the twenty-fourth week, and egg and fish about the thirty-fifth week. Cod-liver oil was given from a few weeks of age and orange juice at the twentieth week. The infant was fed the amounts of food she would take. On the whole she was slow to accept new foods.

Growth. Fig. 1 shows for each week of the study the energy intakes, the weight of the infant and the gain in weight. The weight at one year was $23 \mathrm{lb}$. $7 \mathrm{oz}$., giving a gain in the year of $16 \mathrm{lb} .4 \mathrm{oz}$. Had she not had bronchitis in the eleventh month the weight at one year would have been about $24 \frac{1}{2} \mathrm{lb}$., giving an annual gain of about $17 \mathrm{lb} .5 \mathrm{oz}$. This is greater than the mean annual gain of $14 \mathrm{lb} .2 \mathrm{oz}$. given by Parfit (1951) and $14 \mathrm{lb} .7 \mathrm{oz}$. by Hammond (in press) for a group of infants in Leeds. The likely gain of $17 \mathrm{lb} .5 \mathrm{oz}$. in the year was one and a half standard deviations above the mean given by Parfit (1951).

Table 1 shows the infant's weight gains in spells of four weeks and those found by Hammond. Progress was slow up to 16 weeks due to poor gains during the time of breast feeding, but by 20 weeks progress was just above normal; then for a few weeks it was rapid. Her weight gains in the four quarters (13 weeks) of the year and those found by Parfit (1951) are given in Table 2a. The third quarter was a time of very rapid gain.

The 43 weeks under review fall into three phases of growth, namely: (1) steady progress, a gain of $8 \frac{1}{2}$ oz. a week between February 24 and May 19, that is, from the age of $9 \frac{1}{2}$ weeks to $21 \frac{1}{2}$ weeks; (2) rapid progress, a gain of 9 óz. a week between May 26 to July 14, that is, from the age of $22 \frac{1}{2}$ weeks to $29 \frac{1}{2}$ weeks, after a loss in weight of $9 \mathrm{oz}$. in one week due to about seven days of diarrhoea and vomiting; and (3) steady but reduced progress, about $4 \mathrm{oz}$. a week, from July 14 to November 24 , that is, from the age of $29 \frac{1}{2}$ weeks to $48 \frac{1}{2}$ weeks, after which there was a loss in weight due to bronchitis.

The slower rate of gain in weight in (3) was partly due to the child becoming more active. About the middle of July she was put to kick on the floor, and by the end of the year she was crawling quite well.

The infant was ill five times during the study. A cold in March, mumps in April and a cold in October were slight, while diarrhoea and vomiting in May and bronchitis in December were more severe. Each illness had an effect on growth. Thus, the gain in weight was less than it had been 


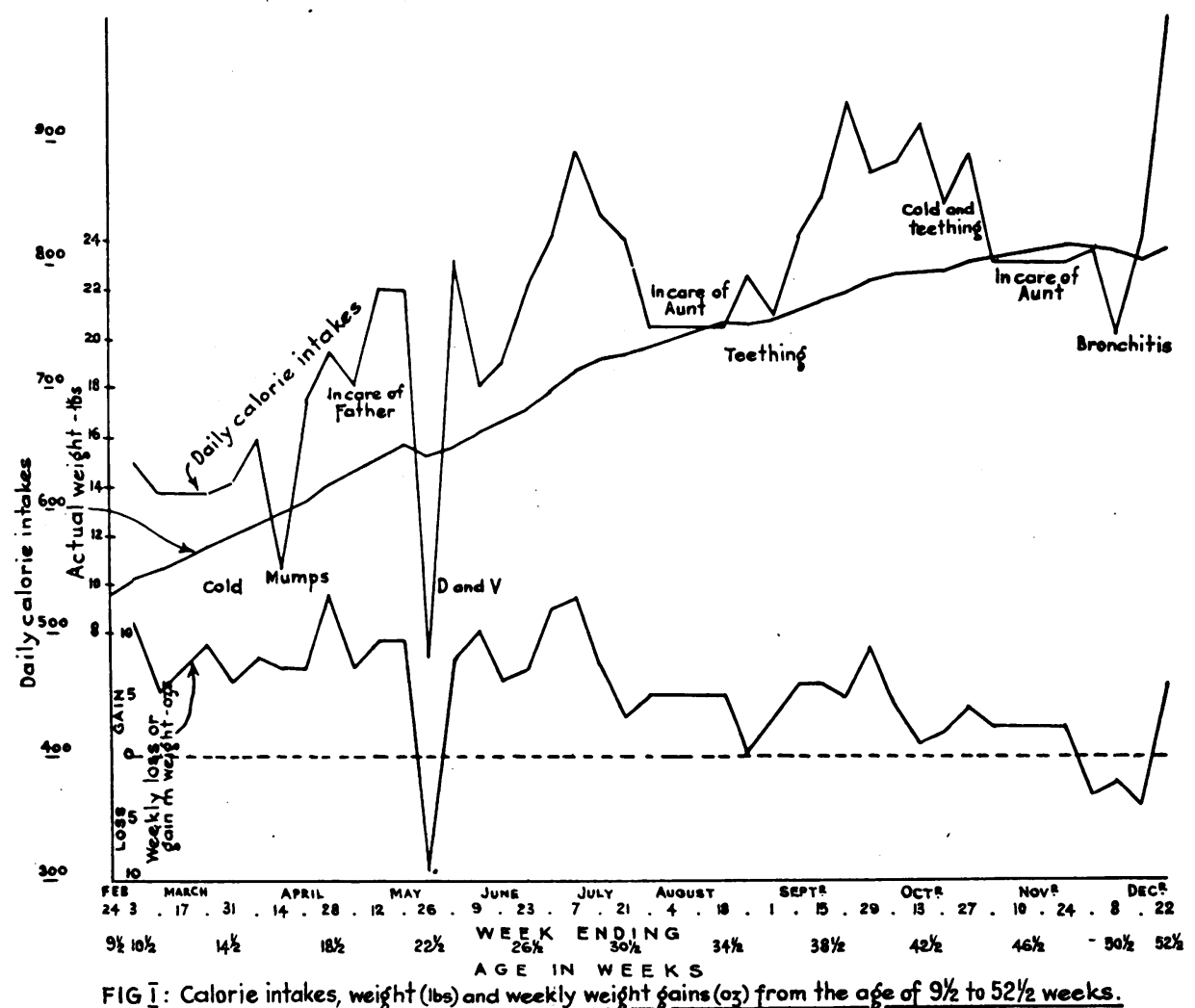

by about $2 \mathrm{oz}$. a week due to the first cold, during mumps by about $1 \mathrm{oz}$. a week and during the second cold, when she was teething, by 2 to $3 \mathrm{oz}$. During the bout of diarrhoea and vomiting there was a loss of $9 \mathrm{oz}$. in one week, and again a loss of $9 \mathrm{oz}$. in three weeks due to the attack of bronchitis.

TABLE 1

Weight Gains in Spells of Four Weeks

\begin{tabular}{|c|c|c|c|c|}
\hline \multirow[b]{2}{*}{$\begin{array}{c}\text { Age } \\
\text { (weeks) }\end{array}$} & \multicolumn{2}{|c|}{ Gains from Birth (lb. oz.) } & \multicolumn{2}{|c|}{ Four-weekly Gains (oz.) } \\
\hline & $\begin{array}{l}\text { Present } \\
\text { Subiect }\end{array}$ & Hammond & $\begin{array}{l}\text { Present } \\
\text { Subject }\end{array}$ & Hammond \\
\hline $\begin{array}{r}8 \\
12 \\
16 \\
20 \\
24 \\
28 \\
32 \\
36 \\
40 \\
44 \\
48 \\
52\end{array}$ & $\begin{array}{rr}1 & 11 \\
3 & 9 \\
5 & 7 \\
7 & 11 \\
8 & 13 \\
11 & 1 \\
12 & 9 \\
13 & 7 \\
14 & 14 \\
15 & 12 \\
16 & 8 \\
16 & 4\end{array}$ & $\begin{array}{rr}2 & 10 \\
4 & 8 \\
6 & 5 \\
7 & 8 \\
8 & 11 \\
10 & 0 \\
11 & 0 \\
11 & 12 \\
12 & 9 \\
13 & 3 \\
13 & 9 \\
14 & 7\end{array}$ & $\begin{array}{r}\overline{30} \\
30 \\
36 \\
18 \\
36 \\
24 \\
14 \\
23 \\
14 \\
12 \\
4\end{array}$ & $\begin{array}{r}\overline{30} \\
29 \\
19 \\
19 \\
21 \\
16 \\
12 \\
13 \\
10 \\
6 \\
14\end{array}$ \\
\hline
\end{tabular}

Teething was rapid towards the end of August and the child failed to gain weight in one week.

Energy Intake. The energy intakes varied greatly from week to week. For some, this was due to illness, but in others there was no obvious cause except that the baby was not eating well. Thus, the daily calorie intake during the week ending June 19 was 699 , and it rose to $719,780,824$ and 893 in the next four weeks. After she had been off her food the energy intakes became greater than before. Thus, after the attack of bronchitis, the daily calorie intake rose to 988 , a value higher than ever before. Fig. 1 shows that growth and calorie intakes went hand in hand. When the child was in the care of her father or her aunt the energy intakes were lower than when she was in the care of her mother. The father and aunt were told how to prepare the feeds, but the father gave more sugar and less cereals and the aunt gave less sugar and less cereals. The result was that energy intakes were less.

Table $2 a$ gives the data on growth and energy intakes for the second, third and fourth quarters 
TABLE 2A

Growth and Calorie Data for the Four Quarters (13 weeks) OF THE YEAR

\begin{tabular}{|c|c|c|c|c|c|c|c|c|}
\hline Quarter & $\begin{array}{r}\text { We } \\
\mathbf{G} \\
\text { (lb. }\end{array}$ & $\begin{array}{l}\text { ight } \\
\text { ain } \\
\text { oz.) }\end{array}$ & $\begin{array}{r}\text { We } \\
\mathrm{G} \\
(\mathrm{Pa} \\
19 \\
\text { (lb. }\end{array}$ & $\begin{array}{l}\text { ight } \\
\text { ain } \\
\text { rfit, } \\
51 \text { ) } \\
\text { oz.) }\end{array}$ & $\begin{array}{c}\text { Average } \\
\text { Weekly } \\
\text { Weight } \\
\text { Gain } \\
\text { (oz.) }\end{array}$ & $\begin{array}{l}\text { Daily } \\
\text { Calorie } \\
\text { Intake }\end{array}$ & $\begin{array}{l}\text { Calorie } \\
\text { Intake } \\
\text { (per lb. } \\
\text { body } \\
\text { weight) }\end{array}$ & $\begin{array}{l}\text { Holt and } \\
\text { Fales } \\
\text { (1921) } \\
\text { Standard } \\
\text { (calories } \\
\text { per lb. } \\
\text { body } \\
\text { weight) }\end{array}$ \\
\hline $\begin{array}{l}\text { 1st } \\
\text { 2nd } \\
\text { 3rd } \\
4 \text { th }\end{array}$ & $\begin{array}{l}4 \\
5 \\
4 \\
1\end{array}$ & $\begin{array}{r}2 \\
10 \\
11 \\
13\end{array}$ & $\begin{array}{l}4 \\
4 \\
2 \\
2\end{array}$ & $\begin{array}{r}11 \\
3 \\
14 \\
6\end{array}$ & $\begin{array}{l}5 \cdot 1 \\
6 \cdot 9 \\
5 \cdot 8 \\
2 \cdot 2\end{array}$ & $\begin{array}{l}\overline{686} \\
803 \\
841\end{array}$ & $\begin{array}{l}\overline{48} \\
42 \\
37\end{array}$ & $\begin{array}{l}\overline{51} \\
47 \\
45\end{array}$ \\
\hline
\end{tabular}

TABLE 2B

Growth and Calorie Intakes in Three Phases of Growth

\begin{tabular}{|c|c|c|c|c|c|}
\hline Period & $\begin{array}{l}\text { No. of } \\
\text { Weeks }\end{array}$ & $\begin{array}{c}\text { Weight } \\
\text { Gain } \\
\text { (oz./week) }\end{array}$ & $\begin{array}{l}\text { Daily } \\
\text { Calorie } \\
\text { Intake }\end{array}$ & $\begin{array}{c}\text { Calorie } \\
\text { Intake } \\
\text { (per lb. } \\
\text { body } \\
\text { weight) }\end{array}$ & $\begin{array}{c}\text { Holt and } \\
\text { Fales (1921) } \\
\text { Standard } \\
\text { (calories per } \\
\text { lb. body } \\
\text { weight) }\end{array}$ \\
\hline $\begin{array}{l}\text { Feb. 24-May } 19 \\
\text { May 26-July } 14 \\
\text { July 14-Nov. } 24\end{array}$ & $\begin{array}{r}12 \\
7 \\
19\end{array}$ & $\begin{array}{l}8 \cdot 2 \\
9 \cdot 0 \\
3 \cdot 9\end{array}$ & $\begin{array}{l}665 \\
794 \\
819\end{array}$ & $\begin{array}{l}55 \\
46 \\
38\end{array}$ & $\begin{array}{l}53 \\
48 \\
45\end{array}$ \\
\hline
\end{tabular}

(13 weeks) of the child's life. Table $2 \mathrm{~b}$ gives the same kind of data for the three phases of growth (1), (2), (3) above. Both of these Tables show that total calorie intakes increased, but that calorie intakes per $1 \mathrm{~b}$. of body weight decreased with increase in age. During the 19 week stretch from the age of $29 \frac{1}{2}$ to $48 \frac{1}{2}$ weeks, when the gain was about $4 \mathrm{oz}$. a week, the calorie intake was only 38 per $\mathrm{lb}$. of body weight. Tables $2 \mathrm{a}$ and $2 \mathrm{~b}$ also show the calorie intakes per lb. of body weight based on data given by Holt and Fales (1921). For the early months the actual intakes were much the same as those given by Holt and Fales but in the fourth quarter and the 19 weeks from the age of $29 \frac{1}{2}$ to $48 \frac{1}{2}$ weeks they were much less than the standards given by Holt and Fales.

The Intake of Nutrients. For the whole time of the study protein intakes were $30-40 \mathrm{~g}$. daily, fat about 30 g., calcium $1-1 \frac{1}{2}$ g., iron $1 \mathrm{mg}$. daily up to about 12 weeks of age rising to $10 \mathrm{mg}$. at about 16 weeks; vitamin A just over 1,000 i.u. up to the twenty-fourth week, rising to 4,000 i.u.; vitamin B about 300 i.u. until 17 weeks, rising to 600 i.u., and ascorbic acid about $8 \mathrm{mg}$. up to 20 weeks, rising to about 30 to $40 \mathrm{mg}$. The intakes of vitamins $A$ and $\mathrm{C}$ from the normal diet, that is, without cod-liver oil or orange juice, were about 1,000 to 1,500 i.u. daily of $\mathrm{A}$ and about $8 \mathrm{mg}$. daily of $\mathrm{C}$ up to about 23 weeks, rising to about $30 \mathrm{mg}$. after the twentythird week.

\section{Comment}

The date for this single infant are given simply to show what can be learnt from a study of the diet, growth rate and health record of the same subject over some months. Such data for even a small group of infants would be of much value in showing how these and other factors react and their bearing on the rearing of infants.

\section{REFERENCES}

Holt, L. E. and Fales, H. L. (1921). Amer. J. Dis. Child., 22, 371. 